\title{
Retraction
}

\section{Retracted: Design of Satellite Attitude Control Algorithm Based on the SDRE Method Using Gas Jets and Reaction Wheels}

\author{
Journal of Engineering \\ Received 21 May 2014; Accepted 21 May 2014; Published 26 May 2014 \\ Copyright (C) 2014 Journal of Engineering. This is an open access article distributed under the Creative Commons Attribution \\ License, which permits unrestricted use, distribution, and reproduction in any medium, provided the original work is properly \\ cited.
}

The article titled "Design of Satellite Attitude Control Algorithm Based on the SDRE Method Using Gas Jets and Reaction Wheels" [1] has been retracted as it is essentially identical in content with a previously published paper "Luiz C. G. de Souza, Victor M. R. Arena, Design of Non Linear Controller for a Satellite Attitude Control Simulator, In Frontiers in Aerospace Engineering (FAE), 2012, Vol. 1, issue 1."

\section{References}

[1] L. C. G. de Souza and V. M. R. Arena, "Design of satellite attitude control algorithm based on the SDRE method using gas jets and reaction wheels," Journal of Engineering, vol. 2013, Article ID 318072, 8 pages, 2013. 